\title{
SECURITY AND SAFETY OF TOURISTS AS A FACTOR FOR SUSTAINABLE TOURISM, BASED ON THE EXAMPLE OF BULGARIAN BLACK SEA RESORTS \\ Daniela V. Georgieva ${ }^{1}$, Diyana Bankova ${ }^{2}$
}

\begin{abstract}
Different types of crimes are factors negatively affecting tourism worldwide. However, managers and even tourists themselves are refraining from submitting crime reports and whistleblows. The main goal of the study is to analyze the attitude of the hotels' managers on the Bulgarian Black Sea coast, regarding the submission of whistleblows to the competent authorities. In particular, managers of hotels in Albena, Golden Sands, Dunes, St. Constantine and Helena, and Sunny Beach are studied. The main research hypothesis is that hotel managers should ensure the safety of guests by reducing gaps in the control environment, preventing financial frauds, helping for environmental protection, and supporting the process of reporting crimes and suspicious behavior in the hotels. However, the current management policy relies mainly on the installed security devices and the Security Department staff. This results in applying no specific internal rules, procedures, and training for nonsecurity department employees, regarding crime identification and timely reporting. The adopted research methods are based on the logical, deductive, and comparative methods, as well as on the methods of analysis and synthesis. For the empirical study, the method of in-depth interviews is used. The results of the study support the literature by presenting more in-depth data regarding the used security devices and assets by Bulgarian Black Sea resort hotels. Also, more data on the attitude of hotel managers on the safety and security of tourists and the submission of whistleblows, as a factor for sustainable development of tourism on the Bulgarian Black Sea coast, is presented.
\end{abstract}

JEL Classification Numbers: Z32, K14, M42, DOI: https://doi.org/10.12955/peb.v2.254

Keywords: hotels' security devices, crime reports, whistleblow, national safety, audit.

\section{Introduction}

The safety and security of tourists are a priority in tourism worldwide. According to the National Strategy for Sustainable Development of Tourism in the Republic of Bulgaria 2014-2030 (NSSDTRB 2014-2030, p.75), one of the destination's strengths is the relatively high level of security. However, among the main threats facing the sector is the growing influence of cross-border crimes, domestic crimes (primary theft), and terrorism. This includes robberies, trafficking and distribution of drugs, money laundering, bomb explosions, robberies during prostitution, loan sharks, assault and murder, rape, fire risk, bookmakers, guest poisoning, etc. (Hughes, 1984, p. 35; Barth, 2006, p. 275; Zhao and Brown, 2009; Beaudry, 1996, p. 94). According to official data from the Annual Bulletin of Police Statistics (ABPS) for 2019 in Bulgaria, the following crimes were committed against persons: 221 murders (art. 115-127 of the Penal Code (PC)); 605 debaucheries (art. 149-159 of the PC) and 2768 bodily injuries (art. 128-135 of the PC). Against the properties of the citizens were committed the following crimes: 1183 robberies (art. 198 - 200 of the PC); 33172 thefts (art. 194-197 of the PC). A total of 23118 crimes were reported as general dangerous crimes, including 1233 arsons (art. 330-333 of the PC) and 6 damages by explosions (art. 333 of the PC) (Ministry of Interior of the Republic of Bulgaria, ABPS, 2019). Drug-related crimes are often prevalent in seaside resorts, which numbers according to ABPS data is 5470. When it comes to the regional administrations of the Black Sea resorts, in Varna city there were 6629 crimes registered against persons and property, while in Burgas city there were 5794 crimes registered. Such data is indicative of gaps in security and safety in the Black Sea resorts. There is a need for more effort and resources to be used so that the safety and security of tourists is ensured (NSSDTRB 2014-2030, p. 81). In this respect, one of the main sub-goals for the development of a favorable natural and business environment for sustainable tourism, is the conditions for the security and safety of tourists in Bulgaria to be improved. It should be done through (NSSDTRB 2014-2030 action plan for the period 2017-2020, p. 4):

- The development of a separate Counter-Terrorism Plan in the Tourism sector which is related to the National Counter-Terrorism Plan, following the Counter-Terrorism Act.

- The assistance to the Ministry of Interior when planning tourists' security measures in the national resorts.

- The interaction with competent authorities for the organization and maintenance of a high level of traffic safety within tourist places and around the tourist points, including in seaside resorts.

\footnotetext{
1 International Business School - Botevgrad, Bulgaria. E-mail address: dgeorgieva@ibsedu.bg; danielagr999@gmail.com. ORCID: https://orcid.org/0000-0002-5752-0344

${ }^{2}$ Counteraction to Crime and Public Order Protection, Police Faculty, Academy of the Ministry of Interior, Sofia, Bulgaria. E-mail address: diyanabankova@gmail.com.
} 
- The interaction with competent authorities for the establishment of a safe and secure access regime in the resorts.

- The interaction with competent authorities for maintaining a high level of safety within facilities in the tourist places, tourist points, and sites.

Each of these components is important for creating additional security for tourists. Still, the national legislative framework does not currently provide a significant variety of methods related to the prevention of the mentioned types of crimes, especially in tourist accommodation places. In this respect, the safety of the guests is the main responsibility of hotels and their management. Based on the "from general to particular" principle, as well as on the relationship between crimes committed in resorts and those at hotels, the object of analysis in the first place is the different types of crimes that could be committed in the Black Sea resorts in Bulgaria. In the second part of our research, the measures and devices used to prevent the outlined types of crimes in hotels are analyzed.

\section{Theoretical framework}

Without generalizing, John Fay (2007) defends the idea that crime covers 3 main areas: conventional, economic, and environmental. Conventional crime (also called "domestic crime") is associated with offenses of the following nature: theft; robbery; rape; murder; piracy; abduction, alcohol and drug abuse. This type of crime should not be considered in the same way as "organized crime". Organized criminal groups (OCGs) are those in which more than three people participate jointly (art. 93, para. 20 of the Crime codex). For example, terrorist groups are OCGs of a conventional nature, which also negatively affect tourist attendance. According to data from the Global Terrorism Index (2020), Bulgaria ranks $119^{\text {th }}$ from a total of 163 surveyed countries at risk of terrorist attacks. The last terrorist attack in Bulgaria was in 2012 at Sarafovo Airport in the city of Burgas. In this respect, Bulgaria can be considered as one of the countries in Europe with the least terrorist attacks. This is an exceptional advantage in terms of the security and safety of tourists visiting Bulgarian Black Sea resorts. Concerning terrorist attacks, it is necessary to analyze their financial operation, more precisely to trace the economic crime (money laundering and others). The more serious problem is when an economic crime is organized and it's focused on tourism. From the point of view of the Bulgarian Black Sea coast, there is data for committed crimes (art. 319 a, para 1 of the PC) which are related to the poor management of hoteliers and the low levels of information protection. In particular, but not only, bank transfers made by foreign users but redirected to a foreign bank account and not to the account of the hotel. European legislation has contributed to speeding up the imposition of sanctions on perpetrators. As the main method used by the Prosecutor's Office of the Republic of Bulgaria is the so-called "European Investigation Orders" (EIO) (European investigation order, 2021) and also "European Arrest Warrants" (EAW) (The European arrest warrant, 2021). The European body, called "Eurojust" creates standardized forms in which the authorities indicate the composition of the crime and the grounds for accusing the victim or perpetrator. After that, it is sent to the competent collegial body in the countries of the European Union. Because foreign nationals can become victims of crime in our resorts, through the EIO and EAW pre-trial proceedings are initiated more expeditiously. This method facilitates EU law enforcement competent authorities. Apart from the fact that European law fights against domestic crime, it also includes organized crime. In 2019, local tabloids (Cocaine from the "successful international operation" surfaced in Sunny Beach within a week, 2019) reported that a significant amount of drugs (about 150 $\mathrm{kg}$ of cocaine) surfaced around the Black sea city of Shabla. Law enforcement authorities, with the help of the Romanian collegial authorities, found that it was an organized crime group that transported drugs. In this case, it is important to point out the European police cooperation (ENP). When it comes to the ENP, the Joint Investigation Teams (JITs) should also be mentioned. Nikolov (2021) and Europol present them as a model agreement between at least $2 \mathrm{EU}$ member states (however, non-member countries may also participate, but not as initiators). The main goal is to fight organized crime. Eurojust contributes to the financing of these kinds of operations. Significant results in combating crime are achieved through the JITs. In this respect, it is necessary to pay attention to the fact that tourists can also be potential perpetrators of crimes. Many OCGs involved in the theft of payment card data through skimming devices "disguise themselves as tourists". The same goes for pickpocketing. In addition to the actions of operational and law enforcement agencies, hotel management is essential for the sustainable development of tourism, based on the safety and security of tourists. Hotel business management is also associated with transparent financial policy. The people who have access to financial and accounting 
information and the management decisions are primarily the auditors. Although they are not direct participants in the operational-investigation activities, they have access and competence to the managers' economic data. Additionally, they are committed to report suspicious financial transactions to competent authorities. For this purpose, Table 1 presents some problems found by financial auditors in the financial statements of the Bulgarian Black Sea resorts under review.

\begin{tabular}{|c|c|c|c|}
\hline Resorts & $\begin{array}{c}\text { Auditor`s opinion } \\
\text { about the individual } \\
\text { financial statements }\end{array}$ & $\begin{array}{c}\text { Auditor`s opinion about } \\
\text { the consolidated financial } \\
\text { statements (CFS) }\end{array}$ & Principal audit procedures about \\
\hline Albena & Unmodified opinion & Unmodified opinion & $\begin{array}{l}\text { The emphasis of Matter (EM) is } \\
\text { Covid 19. CFS will be published } \\
\text { later. }\end{array}$ \\
\hline $\begin{array}{l}\text { Golden } \\
\text { sands }\end{array}$ & Qualified opinion & Qualified opinion & $\begin{array}{l}\text { Comment on receivables and their } \\
\text { impairment, and inventories. } \\
\text { There is significant uncertainty as } \\
\text { to the company's to going concern } \\
\text { basis. EM is Covid } 19\end{array}$ \\
\hline \begin{tabular}{|l|} 
Saints \\
Constantine \\
and Helena \\
\end{tabular} & Unmodified opinion & Unmodified opinion & $\begin{array}{l}\text { EM is Covid 19. CFS will be } \\
\text { published later. }\end{array}$ \\
\hline Duni & Unmodified opinion & Unmodified opinion & $\begin{array}{l}\text { EM is Covid 19. Comment on } \\
\text { receivables. }\end{array}$ \\
\hline $\begin{array}{l}\text { Sunny } \\
\text { beach }\end{array}$ & Unmodified opinion & - & - \\
\hline
\end{tabular}

The opinions expressed in the audit reports regarding the individual and consolidated financial statements are largely unmodified. The exception is the resort Golden Sands. Most of the resorts have problems with receivables and their impairment. Another drawback is the delay in issuing consolidated statements. Almost all of the auditors pay attention with emphasis to COVID-19, pointing out the medical security needed, and how it would reflect on business processes. The auditors did not find data of fraud and other irregularities. For tourism services to have better quality, it is important how the funds are managed, especially when concerning the ecological policy, recycling and the circular economy. According to Interpol (2020) "environmental crime is the third most lucrative criminal business in the world, after drugs and human trafficking." The scope of environmental crime includes the redevelopment of the Bulgarian Black Sea coast to ecological zones, as well as the pollution of the sea which is based on various types of waste disposals by factories, hotels, and restaurants. This repulses both Bulgarian citizens and foreign tourists. From a legal point of view Hristova (2018, p. 55) argues that "today more than ever the international community needs effective legal instruments that, however, can change the negative trends and effects" on environmental policies. Such tools should be focused on tourism.

Currently, the practice of reporting crimes to the operational bodies is by submitting crime reports and whistleblows. A report can be submitted both by a victim and by any citizen who has witnessed or learned of a crime. By law, citizens are obliged to inform the prosecutor's office or the police when they know or have witnessed a crime (Prosecutor's Office of the Republic of Bulgaria, 2021). Due to the specifics of the activity, the hotels are part of the stakeholders involved in the process of ensuring the safety of tourists and their belongings. Furthermore, hotels are the most likely place for a crime incident to occur (Jacqui, 1999, p. 4). In this respect, they are involved in reporting and interacting with the competent authorities. Hotels use various devices and measures to protect their guests including: hiring internal or external security guards, alarm systems and surveillance systems, electronic hotel locks, safes, having appropriate architecture designs of the building, parking lot and premises, etc. (Handbook, Part I, 2020; Hayes and Ninemeier, 2006, p. 410; Nadel, 2009). The scope of the mentioned type of crimes gives us a reason to conduct a deeper analyzes of the devices and measures used by hotels to assure the safety of tourists. The main risks, associated with safety in hotels (and hotels' restaurants and bars), are primarily crimes against property and general dangerous crimes. They are based on various theories aiming at ensuring the protection of tourists. Without belittling their importance for this study 
the concept of defensible space theory is taken into account. In particular, the idea is that hotels mainly rely on employees and guests to report criminal incidents. Burstein $(1975$, p. 65) argues that not to tarnish the hotel's image, the management may hide some of the information, especially if it is related to security. According to Wood $(2013$, p. 21), this may lead to a failure of reporting the crime to the competent authorities. For this reason, the authors choose to study the opinions of hotel managers in resorts of national importance, defined by Decision №45 to Council of Ministers from 21.01.2005. The scope of these resorts is Albena, Golden Sands, Duni, Saints Constantine and Helena, and Sunny Beach. The main research hypothesis is that hotel management should be directly involved in ensuring safety, reducing gaps in the control environment, and supporting the process of reporting whistleblows to the competent authorities. However, the current management policy does not include enough internal rules, procedures, and training for crime identification, timely reporting, and ensuring the safe stay of tourists by non-security department staff. This is so because managers rely primarily on the security department staff and the installed safety devices, which however are not focused on the risk of terrorism, financial frauds, and environmental protection. The adopted research methods are based on - logical, deductive, and comparative methods, as well as on the methods of analysis and synthesis. For the empirical study, the method of in-depth interviews is used. The results of the study support the literature by presenting more data on the devices, systems, and facilities used by hotels to ensure the safety and security of guests. A more in-depth analysis of the relationship between hotel managers and the competent authorities when submitting whistleblows, as a factor for sustainable development of tourism on the Bulgarian Black Sea coast, is presented.

\section{Research methodology}

The collection of qualitative data is based on the method of in-depth interviews. They are conducted during the January-February 2021 period. The target group covers hotel managers in the Black sea resorts of national importance. Due to the current health situation with the development of COVID-19, most of the interviews are conducted by telephone or by using applications for conference video calls. A questionnaire of three main blocks of questions is developed. The first block aims at establishing how respondents assess security on the Bulgarian Black Sea coast. The second block contains questions regarding the currently used devices and equipment by the hotels to ensure the safety and security of the guests. Also, questions regarding the training of hotels' staff to identify and prevent crime are included. The third block of questions aims at assessing the interaction of hotels with the competent authorities when reporting crimes, as well as identifying the adopted and applied internal rules, procedures, and training in cases of crimes. At the beginning of each interview, explanations are given by the interviewers, and the average duration of the interviews is 30 minutes.

\section{Data analysis results}

Within the study, 29 respondents took part in the interviews of which 14 were females, and the rest (15) were males. The managers of 4-star $(69 \%)$ and 3-star (24.2\%) hotels predominate, while to a lesser extent there are some representatives of management from hotels with $5(3.4 \%)$ and 2 stars (3.4\%).

The majority of interviewees (66\%) agree that the Black Sea resorts in Bulgaria are safe for tourists. However, they note that the most common crimes are prostitution, theft, pickpocketing, financial fraud (mainly when exchanging currency at exchange offices), and drug trafficking. To the question "What crimes were committed in the hotel you manage?", $48 \%$ of the interviewees stated theft of hotel guests' belongings; $48 \%$ - vandalism; $41 \%$ - theft of money; $24 \%$ - prostitution; $17 \%$ - attack of guests; $10 \%$ trafficking, sale or consumption of drugs; $7 \%$ - assault on an employee; $3 \%$ - rape. More than half of the managers (59\%) state that such crimes have not only occurred in the hotels entrusted to them but that they know about cases in other accommodation places. Nearly $48 \%$ of the respondents say that at their hotels, an external security company is used, and the percentage of those who trust an internal security department is equivalent. The rest use specialized devices and systems, mainly installed monitoring systems (93\%) and alarm systems (nearly 65\%). Two of the interviewees note that they use a perimeter security system, radio sensors, and barriers for motor vehicles. However, regardless of the installed devices, the managers say that they also rely on security guards to make periodic tours of the premises. To minimize the possibility of terrorist attacks and armed robberies, a metal detector door is installed in one of the hotels. In 23 of the hotels there is a panic button at the reception, and in 15 such is installed in the hotel rooms. To prevent crimes against the property of the guests, 25 hotels have safes at the reception, and 19 have placed personal safes in the hotel rooms. Besides, 9 of the interviewees share 
that they have a mobile access control system, 4 - a biometric reader, and 1 - a secret key to lock the rooms. Although only two of the hotels use an elevator control panel for the hotel locking system (the elevator can only work with a staff or hotel guest cards), 8 of the interviewees indicate that as an additional measure there is a panoramic elevator installed. Panoramic elevators are used to reduce the possibility of thefts and crimes inside them. The use of various and diverse forms and tools to ensure the safety of hotel guests is the reason why nearly $52 \%$ of respondents do not conduct training or require special training from non-security staff to identify and prevent crime. Besides, $66 \%$ of managers believe that their staff is trained enough and can handle a crime committed at the hotel. For this purpose, $21 \%$ require employees to undergo special training for identifying crimes and submitting whistleblows, and for $7 \%$ this is a requirement for job applicants in the hotel.

Regarding the interaction with the competent authorities, 52\% of the interviewed managers state that they know about hotels that have reported crimes. At the same time, they say that their guests $(41 \%)$ or hotel employees (52\%) also reported crimes to the police. In 25 hotels the person authorized to report this is the manager, besides him in 22 hotels this is also the receptionist (front office), in 11 - the security, and in 6 - each staff member. The majority of managers (76\%) state that they do not have a specific procedure for identifying and reporting. From all of the interviewees who answered that they have such a procedure, $43 \%$ state that it is related to the direct call to 112 for emergency calls. $29 \%$ - require immediate communication with the manager, $14 \%$ state that the procedure is related to notifying the hotel security, and in an equivalent percentage, the managers specified that the staff is first required to notify their supervisors. When answering the question "What difficulties did you have in reporting a crime to the competent authorities?", most of the interviewees agree on the existence of a language barrier between police representatives and tourists. In particular, the lack of an interpreter or language competence is a reason for a hotel employee to accompany the guest and translate when reporting a crime signal, which is considered a weak point in the overall system. Also, "bureaucracy, slow law procedures, slow response to a whistleblow and crime reports, lack or reduced administrative and technical capacity, and many unnecessary questions by the police representatives" are additional difficulties that managers have encountered when reporting crimes. The view that the competent authorities do not have sufficient powers or are not interested in investigating thefts of amounts below EUR 500 is also stated by the respondents.

\section{Discussions}

The opinions of the interviewed managers are indicative of the existence of enhanced security measures in hotels with more than three stars. Logically, the security budget of the hotels is highly dependent on the number of stars, and hence on the price of the offered hotel services. In this respect, hotel managers of three or fewer stars' hotels consider it necessary to strengthen security by hiring "young" security guards and install more video surveillance devices. While the representatives of hotels with more stars focus their efforts on the modernization of already installed devices and facilities to ensure safety. Although the managers share the common vision of a high level of security in the Black Sea resorts, there are criticisms of the "lack of adequate measures by the law enforcement agencies". This is causally dependent on the fact that "police actions are not preventive, but when there is already a crime". It is noteworthy, however, that there is a difference in the number of hotels for which the interviewees know that a crime has occurred (17) and the number of those who reported the crime (15). This can partly be explained by the stated difficulties in reporting and by the existence of a personal reluctance (of managers or tourists) to do so. Such findings are in line with the idea of Zhao and Brown $(2009$, p. 21) that robberies might not be reported. Although during the interviews the interviewers did not sense a lack of willingness of the interviewees to hide a crime, due to the limitations of the survey, as well as the internal desire of the managers to build a positive image of the hotel (Beaudry, 1996), we could not completely ignore this factor. Interviewees see the crimes against property as the most common in the hotels. These findings support the studies of Beaudry (1996) and Hughes (1984). Because of that, the used devices and measures aimed to prevent primarily theft and based on the literature review could be considered commonly used in the hotel industry (Hayes and Ninemeier, 2006, p. 410; Beaudry, 1996, p. 68; Nadel, 2009, p. 1.26). To a lesser extent, however, managers rely on non-security staff to identify and prevent crime. The percentage of interviewees who require similar competencies from their employees or offer specialized training is relatively low. However, there are a high percentage of interviewees $(59 \%)$ who have written internal rules for identifying crimes by their staff. This can be 
explained in the first place by the audit path requirements. The existence of written rules is mainly administrative measures which, if not practically introduced and explained to the staff periodically, are ineffective and inefficient. Secondly, the legal regime in Bulgaria requires the writing of numerous procedures and internal rules, and in most cases, the managers are not fully acquainted with the document flow. In this respect, when asked whether an organization has a certain internal normative act, in order not to contradict the legislation, managers answer positively, regardless of the reality. An issue identified by the interviewees is the weak language competencies of the representatives from the police departments. This can be considered as a factor negatively influencing the reporting of crimes and is a reason to suggest that police may need to review their procedures for dealing with international tourists who become victims of crime. Other negative factors, based on the interviews, are the presence of some bureaucratic burdens, as well as the lack of capacity on the part of the competent authorities, which reflects to a lack of involvement in the theft of small amounts or low-value items. Based on the outlined opinions, a subsequent analysis of the attitude of the tourists and the law enforcement agencies to the problematic moments set by the managers is needed. Future research in the field could include a comparative analysis based on good practices from abroad. However, these are not subjects of study in the current paper.

\section{Conclusion}

As a conclusion based on the analyses, it can be stated that the interviewees use the usual security measures and devices, which are not aimed at the specific prevention of terrorism, financial or environmental crimes, but at crimes of a general nature. There are some gaps in Bulgarian tourism and legislation in terms of security and safety in hotels on the Black Sea coast. Because of that, it is necessary changes to be made. As such, hotels' corporate updates of security and safety policies can be mentioned, in addition to the implementation of devices and systems related to the security of payments from tourists and the implementation of additional tests and procedures by financial auditors related to financial security. The legal self-awareness of tourists and Black Sea hotel managers to report crimes should also be encouraged. Tourist services are complex. Therefore, efforts need to be focused on training nonsecurity department employees to provide not only better service but to minimize the risk of crimes. This is to ensure that hotel staff is proactive rather than reactive. The hotel's security features and devices must be timely improved and renovated. Hotel management should take into account the possibility of different types of terrorist attacks when developing their security measures as well as to pay more attention to the environmental protection.

\section{Acknowledgments}

This study is financed with funds under the project "Model Development and Testing for Monitoring and Evaluation of Sustainable Tourism Development in Bulgaria (after the example of national resorts)" financed by the National Fund "Scientific Research ", contract No КП06-Н25/3 from 13.12.2018.

\section{References}

Barth, S. (2006). Hospitality Law. Managing legal issues in the hospitality industry. Hoboken.

Beaudry, M. (1996). Contemporary Lodging Security. Butterworth-Heinemann.

Burstein, H. (1975). Hotel Security Management. London, Praeger.

European investigation order, Retrieved February 27, 2021, from https://www.eurojust.europa.eu/judicialcooperation/eurojust-role-facilitating-judicial-cooperation-instruments/european-investigation-order-eio.

Fay, J. (2007). Encyclopedia of Security Management. Elsevier, USA.

Global Terrorism Index 2020: Measuring the Impact of Terrorism, Institute for Economics \& Peace, Sydney, Retrieved February 20, 2021, from http://visionofhumanity.org/reports.

Godishen byuletin na politseřskata statistika [Annual Bulletin of Police Statistics] (2019). Ministry of Interior of the Republic of Bulgaria, Retrieved February 20, 2021, from https://tinyurl.com/vc9uv5h4

Handbook, Part I: Lessons for Terrorism Prevention from Literature in Related Fields (2020), Retrieved May 05, 2021 from https://icct.nl/publication/lessons-for-terrorism-prevention-from-literature-in-related-fields/.

Hayes, D., Ninemeier, J. (2006). Foundation of Lodging Management. Prentice Hall.

Hristova, A. (2019). Challenges for international environmental law in the transition to a low-carbon and energy-efficient economy. Protection of environment: interaction betweem internation and national law. Proceedings of the Roundtable Discussion XVII Blischenko Congress, Moscow April 14th, 2018, Peoples' friendship university of Russia, pp. $52-55$.

Hughes, D. (1984). Guide to hotel security. England: Aldershot Hants. 
Interpol marks a decade of tackling serious organized environmental crime (2020), Retrieved February 1, 2021, from https://www.interpol.int/News-and-Events/News/2020/INTERPOL-marks-a-decade-of-tackling-serious-organizedenvironmental-crime.

Jacqui, A. (1999). Crime Against International Tourists. Contemporary Issues in Crime and Justice 1999(43): 1-8. NSW Bureau of Crime Statistics and Research .

Kokainŭt ot „uspeshnata mezhdunarodna operatsiya“ - izpluva na Slŭnchev bryag do sedmitsa [Cocaine from the "successful international operation" - surfaced in Sunny Beach within a week] (2019), Retrieved February 10, 2021, from https://tinyurl.com/uxka7xma

Nadel, B. F. (2009). Building Security: Handbook for Architectural Planning and Design, McGraw-Hill.

Natsionalna strategiya za ustořchivo razvitie na turizma v Republika Bŭlgariya, 2014-2030. [National Strategy for Sustainable Development of Tourism in the Republic of Bulgaria 2014-2030], Updated version 2017, Ministry of Tourism. Nikolov, P. (2021). Savmestni ekipi za razsledvane [Joint investigation teams]. Sofia, AMVR.

Plan za deǐstvie za perioda 2017-2020 kŭm aktualiziranata Natsionalna strategiya za ustořchivo razvitie na turizma v Republika Bŭlgariya, 2014-2030 [NSSDTRB 2014-2030 action plan for the period 2017-2020], Ministry of Tourism.

Prosecutor's Office of the Republic of Bulgaria, Retrieved January 31, 2021, from https://prb.bg/bg/za-grazhdanite/vprosi-iotgovori.

The European arrest warrant, Retrieved February 27, 2021, from https://ejustice.europa.eu/content_european_arrest_warrant-90-en.do.

Wood, R. (2013). Key Concepts in Hospitality Management. Sage Publications Ltd.

Zhao, J., Brown, M. (2009). Examining Hotel Crimes from Police Crime. Reports. Crime Prevention and Community Safety: An International Journal 11(1): pp. 21-33 